\title{
«Para perpetua memoria». L’Església de Girona de la República al franquisme (1931-1940): un testimoni des del Capítol de la Catedral
}

\author{
JOAQUIM NADAL FARRERAS \\ Universitat de Girona / Institut Català de Recerca en el Patrimoni Cultural (Espanya) \\ orcid.org/0000-0002-8589-7691
}

Presentació: 17 ag. 2016 | Acceptació: 3 oct. 2016 | Publicació: 15 des. 2016

Citació recomanada: NADAL FARRERAS, Joaquim. «"Para perpetua memoria”. L’Església de Girona de la República al franquisme (1931-1940): un testimoni des del Capítol de la Catedral». Franquisme \& Transició. Revista d'Història i de Cultura 4 (2016): 221-254. doi: http://dx.doi. $\operatorname{org} / 10.7238 /$ fit.voi4.3091

Resum: L'article presenta dos textos inèdits de les Actes Capitulars de l'Arxiu Capitular de Girona escrits en la immediata postguerra pel canonge doctoral Dr. Josep Maria Morera Sabater, que mostren com, després dels intents del Consistori municipal republicà de marcar distàncies amb l'Església, aquesta retorna un cop acabada la guerra a les velles complicitats amb l'Estat, que les autoritats eclesiàstiques aprofiten per condemnar el passat recent, assegurar tant la reconstrucció material del patrimoni com el seu finançament i posar les bases ideològiques, però també els valors pragmàtics, del nacionalcatolicisme. Paraules clau: Segona República, Ajuntament de Girona, Guerra Civil espanyola, Capítol de la Catedral de Girona, Bisbe de Girona, Josep Maria Morera Sabater

\section{«Para perpetua memoria». The Church in Girona between the Republic and Franco (1931-1940): An account from the Chapter of the Cathedral}

Abstract. This article presents two unpublished texts from the Actes Capitulars from the Girona Chapter Archives. They were written in the immediate postwar period by the doctoral canon Dr. Josep Maria Morera Sabater, and they show how, after the Republican municipal council had made attempts to establish distance relative to the Church, once the war had finished the latter returned to its old complicity with the state, which the church authorities used to

Nota: Aquest article s'ha elaborat en el marc del Grup de Recerca en Patrimoni Cultural de Catalunya, reconegut per la Generalitat de Catalunya, 2014 SGR 772.

FRANQUISME \& TRANSICIÓ 4 (2016) ISSN 2014-511X PUNCTUM, UNIVERSITAT OBERTA DE CATALUNYA \& FUNDACIÓ CARLES PII SUNYER 
condemn the recent past, ensure the material reconstruction of assets as well as the financing thereof, and lay the ideological foundations and pragmatic values of national Catholicism.

Keywords: Second Spanish Republic, Municipality of Girona, Spanish Civil War, Chapter of Girona's Cathedral, Bishop of Girona, Josep Maria Morera Sabater

És ben conegut que un dels temes que va dominar l'agenda política de la Segona República espanyola va ser la "qüestió religiosa": la reclamació d'una posició laica de l'Estat i la voluntat de posar límits a la preponderància d'una educació confessional que es considerava que xocava amb les més clares essències republicanes. Aquesta demanda venia, però, de lluny, i havia donat peu a alguns projectes reformistes accelerats, que durant la Guerra Civil o bé van ser interromputs o compromesos pels brots iconoclastes i violents de la revolució contra l'Església, els capellans i la gent de dretes, o bé contrarestats reactivament pel nacionalcatolicisme. És just en aquest constext que cal situar alguns fets rellevants al voltant de la "qüestió religiosa" a la ciutat de Girona que afectaven les relacions entre l'Església diocesana i el Capítol de la Catedral amb l'Ajuntament de la Ciutat durant la República i la Guerra Civil. El manuscrit que presentem, inèdit fins ara, illustra la situació que es desencadena a partir de 1939 quan, acabada la guerra, l'Església recupera l'hegemonia, i en quins termes feia el balanç ideològic, material i espiritual de tot el període.

\section{De l'intent de laïcitat republicana (en dos exemples) als anys de la revolució}

Poc després d'un mes d'haver-se proclamat la República, l'Ajuntament de Girona, en sessió plenària celebrada el dia 28 de maig de 1931, va replantejar-se per primera vegada les relacions entre l'Ajuntament i l'Església de Girona, ${ }^{1}$ en un debat sobre la conveniència que el consistori assistís ofi-

1 Comissió de Govern del 29 d'agost de 1930 al 12 de desembre de 1931: «En la ciutat de Girona a vint-i-vuit de maig de mil noucents trenta un: reunit l'Excm Ajuntament per a celebrar sessió pública ordinària que no pogué tenir lloc el dia vint-i-sis per no haver-hi concorregut nombre suficient de Srs regidors per a prendre acords i trobant-se reunits els inscrits al marge, baix la Presidència del Sr. Alcalde D. Miquel Santaló, SS siguent l'hora de reglament va declarar-la oberta. President Sr. San- 
cialment, com havia fet fins llavors, als actes religiosos tradicions locals, que eren en molts aspectes caducs als ulls de la nova majoria republicana:

Va donar-se compte d'un escrit del Bisbat convidant a la Corporació i personal de la seva dependència per a que assisteixi a la processó general del Corpus que haurà de tenir lloc a les sis de la tarda del propvinent dijous 4 de juny. El Sr Palol feu present que existia una proposició relacionada amb la intervenció de l'Ajuntament en actes d'aquesta classe, que pregà es llegís com a base de l'acord a prendre. El Sr President disposà la lectura demanada de dita proposició concebuda en els termes següents: «A l’Excm Ajuntament. Els Regidors que sotscriuen, conseqüents amb la doctrina propagada a la cívica opinió gironina en demanar-li els sufragis; atès a l'ambient de llibertat i de respecte adient al règim republicà, als interessos del Municipi i a la necessitat immediata de definir les relacions de l'Ajuntament amb l'Església, proposa a la Corporació. Primer: Que sigui declarada urgent aquesta proposició. Segon, que entenent que l'atribut específicament humà és la llibertat de pensar fonament de la llibertat de consciència i de la dignitat civil i ciutadana; entenent que en nom d'aquesta llibertat cada un pot acceptar les creències religioses que consideri més adequades a la seva personalitat, entenent que això mateix obliga a les Corporacions públiques a ésser respectuoses amb totes les creencies i a inhibir-se o almenys a no manifestar cap preferència a una determinada per tal de no ferir el sentiment íntim dels veïns i de garantir una convivència fraternal, considerant que la intervenció i contribució de l'Ajuntament de Girona a les manifestacions religioses suposaven una desviació de la missió que li està encomanada, aliena sempre a les qüestions que pertanyen a l'esfera de la conciència individual, sotmet a la consideració del Consistori l'aprovació dels següents acords. 1er. A partir d'aquesta data l'Ajuntament de Girona no assistirà ni intervindrà en cap acte ni manifestació religiosa, fora del que li correspon per a garantir l'ordre i la seguretat pública. 2on. Cap dels representants de l'Ajuntament podrà arrogar-se per aqueixos fins, una representació corporativa ni podrà ésser-li’n atorgada a ningú.

taló. Senyors Vidal, Busquets, Cerezo, Julià, Varderi, Pascual, Rahola, Colomer, Ribas, Vilardell, Tordera, Bassols, Güell, Busquets, Vila, Valls, Tomàs, Bonmatí, Regàs. Vist el contingut del debat també degué assistir-hi Miquel de Palol que no figura al marge», Arxiu Municipal de Girona (AMGi). 
Els Regidors, però seran lliures d'assistir-hi com a Regidors. zer. L’Ajuntament disposarà del material que utilitzava en alguns actes religiosos, segons estimi més oportú en cada cas. 4art. Commemorar la data de 5 de novembre de 1684 , endomassant la Casa de la Ciutat, posant al balcó la gloriosa bandera d'Ultònia i organitzant algun acte cultural per a glossar les gestes cíviques de Girona. 5nt. Contestar a l'amable invitació per assistir a la processó de Corpus de conformitat amb els acords anteriors; trametent còpia d'aquesta proposició i posant a disposició dels organitzadors el material propietat de l'Ajuntament. VE no obstant acordarà. Girona 28 de maig de 1931».

Declarada l'urgència el Sr Tomàs estimà que la Corporació hauria de continuar la tradició de la ciutat, esmentant la conducta i exemple de l'Ajuntament republicà de 1873 qual acord (fol 141 v) sobre la matèria fou a petició seva llegit. Entenguent que no n'hi ha prou amb que's reconegui la facultat d'assistència particular als Regidors, que tampoc podria impedir-se, i demanà s'acordés la assistència en Corporació, o al menys en representació delegada, pels senyors Regidors que ho tinguessin a bé. El Sr. Cerezo defensà la proposició en nom de la llibertat de pensament i del respecte a la consciència particular. S'hi adherí el Sr. Tordera afegint que molts republicans són catòlics. El Sr. Busquets Norat cregué que devia correspondre's a l'atenció del Capítol Catedral i a la tradició de la Ciutat de que són mandataris els Regidors concorreguent en Corporació o en Comissió. El Sr President feu constar, pel que fa a correspondència d'atenció, que s'havia entrevistat amb el Sr. Degà en termes de la major armonia que exclouen tota molèstia. El Sr. Bassols considerà necessari que es votés per parts, aclarint en primer terme si l'assistència personal de Regidors s'entenia facultada amb el caràcter i distintius del càrrec. El Sr. Dalmau ho explicà en aquest darrer sentit, que fou acceptat i incorporat per tant en aclaració a la proposta. Després de diverses manifestacions dels Srs. Rahola, Tordera, Vila, Bonmatí, Palol i President, ordenà aquest darrer passessin a votació els dos primers extrems de la proposta, amb l'aclaració feta i admesa pel Sr. Dalmau, que foren aprovats per 15 vots dels Srs Busquets (V), Colomer, Varderi, Cerezo, Tordera, Dalmau, Palol, Ribas, Rahola, Vidal, Vilardell, Escatllar, Pascual, Julià i President, contra 8 dels Srs Tomas, Valls, Vila, Güell, Bonmatí, Busquets (N.), Regàs i Bassols. Seguidament s'aprovaren per unanimitat els restants extrems de la proposició. El Sr Tordera explicà el seu vot, fent constar que era en contra també de l'autorització de l'ús d'insígnies 
per part del Regidors que hi concorreguessin. Y en sa virtut s'acordà contestar la comunicació del Bisbat amb subjecció a les expressades normes oferint el tàlem acostumat, l'assistència de gegants i nans i l'adopció de mesures de seguretat i policia urbana, segons precedents.

Tres anys més tard, a la sessió del 4 d'abril de 1934, passades ja les eleccions municipals i ara amb un ajuntament amb majoria de les dretes tradicionalistes i regionalistes, se suscità un altre debat de característiques diferents sobre si era pertinent que els treballadors municipals treballessin Dijous i Divendres Sant: ${ }^{2}$

El Sr. Tarrés feu constar la protesta de la comunitat tradicionaslista per haver-se treballat els dies de Dijous i Divendres Sants; expressada en els termes continguts en escrit de què féu entrega i al que es dóna lectura, del tenor següent: «Sento el tenir-me d'aixecar per fer pública la disconformitat i disgust d'aquesta minoria tradicionalista vers l'acord de la Comissió de Govern d'aquesta Corporació Municipal consistent en tenir obertes les oficines i fer treballar les brigades municipals, en la tarda i matí del passat dijous i divendres Sants, i per això no solament ens havem de contentar en manifestar el nostre condol per tal procedir, sinó que també i des d'aquí, aquesta Minoria vol protestar de la manera més enèrgica sobre aquest fet ja que entenem que no solsament queda reduït a una falta de respecte per la significació i santedat d'aquests dos dies, sinó que també fou una coacció vers la lliure consciència d'aquells empleats i obrers municipals que de tot cor, haurien volgut rendir just homenatge a Jesucrist.

No volem recollir veus volants, sinó remarcar dos punts, el primer que nosaltres junt amb els elements de la Lliga Catalana ens presentàrem a les passades eleccions enrolats en una Candidatura dita d'Unió i Defensa Ciutadana, presentant-se aquesta com netament catòlica, per lo que fou apoiada pels

2 Llibres d'actes. Acta del dia 4 d'abril de 1934: «En la ciutat de Girona a quatre d'abril de 1934, convocat l'Excm Ajuntament per a celebrar sessió pública ordinària i trobant-se reunits els senyors Consellers inscrits al marge sota la presidència de l'alcalde Francesc Tomàs, SS, essent l'hora de reglament la declarà oberta. Assistents. Tomàs, Bonmatí, Cervera, Aragó, Busom, Rahola, Vila, Camps, Joivé, Cornellà, Sala, Busquets N, Tarrés, Domènech, Viñas, Meléndez, Malagelada, Gispert, Riera, Gifre, Serra, Busquets V», AMGi. 
elements catòlics d'aquesta ciutat, i quins ens portaren a la victòria, i ara ja el Govern de la Ciutat en les mans de la Lliga Catalana, aquesta fa burla vers els sentiments religiosos dels quins els portaren al Consistori, i cal tenir molt present Senyors, que l'any passat tenint la majoria l'Esquerra, saberen respectar les creències dels seus empleats i obrers, deixant-los en llibertat de treballar o no durant aquests dos dies. No significa lo d'aquest any un sabotatge a l'opinió que ens portà en aquest Consistori per representar-la? I el segon punt en el que aquesta Minoria Tradicionalista vol recolzar-s'hi, és el paràgraf del manifest que als electors de Girona vàrem adreçar-los-hi en data 7 de gener i en nom de la candidatura de Unió i Defensa Ciutadana, quin paràgraf deia així:

«El nom que qualifica la nostra candidatura, diu ja a bastament la significació amb què tots nosaltres anem a la lluita. La nostra candidatura és d'unió i és de defensa, perquè és la resultant d'una entesa entre els partits polítics que l'han proclamada, que mantenint cadascú la seva ideologia i el seu programa, en una i altre coincideixen en aquells principis essencials que la voluntat del país clarament manifestada en les darreres consultes que s'han fet al cos electoral, ha declarat palesament que vol veure respectats en la vida pública. Coincidim i anem units, per tant, en la comunitat de creences i sentiments religiosos i en la conservació de les institucions fonamentals de la nostra civilització cristiana. Estem d'acord que cal defensar amb tota energia el patrimoni espiritual i social de la nostra terra contra la intolerància, el sectarisme, la demagògia que també han invadit els àmbits de la vida municipal. Volem servar fidelment en el govern de la ciutat l'espiritualitat tradicional de Girona, fogar de seculars sentiments religiosos i patriòtics que bateguen en tots els moments gloriosos de la seva història.

No era això un compromís que contrèiem davant el cos electoral de Girona? I perquè no complir-lo, en aquesta primera ocasió? Quins motius poden haver-se presentat des d'allavors fins ara per no correspondre'l? És per ventura, Senyors, que aquest any ja no és tradicional guardar respecte a Jesucrist? És que, senyors consellers de la Lliga Catalana, no representa l'obligar a treballar aquests dies als empleats i obrers municipals, un acte d'intolerància, de sectarisme i de demagògia, que en aquell manifest dèiem anar-hi en contra?

De cap de les maneres aquesta Minoria pot creure que tots aquells senyors que espontàniament signaren el Manifest expressat, estiguin conformes en aquest procedir de la Comissió de Govern i és per lo que aquesta Minoria 
els emplaça perquè junt amb ella, manifestin el seu disgust i disconformitat sobre l'acord que ens ocupa i també voldria sentir de la Minoria d'Esquer$\mathrm{ra}$, amb la qual tant distanciats ideològicament estem, el seu criteri sobre si fou o no procedent el no respectar la llibertat de consciència dels empleats i obrers municipals, perquè així ells poguessin obrar segons els aconsellés llurs consciències.

Desitjaria aquesta Minoria, que es fes constar en acta aquesta protesta, com així mateix voldria veure-la reforçada en una manifestació dels Consellers de Lliga Catalana.»

La Presidència féu constar que les festivitats de què es tracta no són de precepte religiós sinó simplement tradicional, malgrat qual circumstància deixà en llibertat als funcionaris i portà la brigada a llocs on no pogués semblar que s'alterava la solemnitat del dia. Quals explicacions demanà constessin, lamentant amb tot no haver interpretat en aquest punt el criteri de la minoria tradicionalista. El senyor Busquets Norat digué que no discutia els fets, sinó la tendència que representaven i demanà constés en acta la protesta llegida. El senyor Bonmatí digué que havien complert en consciència i amb els seus deures de govern, sense abdicar, enfront d'aquests del seu revisionisme. El senyor Busquets Ventura es manifestà satisfet del respecte a la llibertat de consciència dels obrers, lamentant però que no haguessin treballat els que ho tinguessin a bé el dia de Sant Josep. La Presidència digué que s'havia atès a l'establert generalment pels pactes obrers d'aquesta Ciutat i a l'exemple de la Generalitat de Catalunya, desitjant encara que hi hagués un calendari de treball paccionat.

Els episodis de 1931 i 1934 respectivament són, en definitiva, dos exemples de discrepància dialèctica a escala municipal dirimida en sessió plenària de l'Ajuntament que illustren el clima de tensió social, que en els anys de la República s'havia canalitzat per la via electoral - malgrat alguns episodis insurreccionals dels militars per un costat, i dels obrers i certs governants per l'altre-, però que esclataria en una autèntica explosió revolucionària a partir del 18 de juliol de $1936.3^{3}$ A Catalunya, un

3 Cal fer esment per a aquest període, però també per a tota l'etapa que tractem, dels llibres de Josep Clara, El bisbe de Girona davant la Guerra d'Espanya (1936-1939) (Girona: Ed. Gothia, 1983) FRANQUISME \& TRANSICIÓ 4 (2016) ISSN 2014-511X PUNCTUM, UNIVERSITAT OBERTA DE CATALUNYA \& FUNDACIÓ CARLES PII SUNYER 
cop controlada tècnicament la insurrecció militar, el territori va quedar a la rereguarda dels fronts de guerra. Amb raó o sense, però, es veien enemics a cada cantonada; el risc del quintacolumnisme tenia a tothom en estat d'alerta. La connivència de l'Església amb els sectors més dretans i conservadors de la societat catalana va crear un clima de sospita generalitzada, de manera que les accions indiscriminades contra el clergat, les esglésies, els convents i els elements significats de les dretes - per posició política o econòmica-, es van concretar en actes de persecució i encalçament, saqueig i assassinat. El clima que es va viure a Catalunya els primers mesos de la Guerra Civil va propiciar, per als que es van salvar de les primeres escomeses, el que ja s'ha anomenat "l'exili, o els exilis, de 1936".

La dualitat de poders entre els comitès antifeixistes i les autoritats institucionals de la Generalitat i ajuntaments va crear situacions d'indefensió en uns casos i de connivència en d'altres, però en general va prevaldre la idea que els poders electes i convencionals perdien autoritat davant del nou poder revolucionari. L'esforç per recuperar l'autoritat i la confiança, amb més o menys èxit, fou imminent. Com s'ha fet notar en diversos estudis, els poders instituits mateixos van propiciar, facilitar i ajudar que algunes persones en risc s'exiliessin el 1936, fet que no deixava de ser un reconeixement implícit de feblesa. La importància de totes aquestes qüestions queda prou palesa quan, finalitzada la guerra, tant Carles Pi Sunyer com Pere Bosch Gimpera van dedicar a aquests temes els seus primers i principals informes adreçats a les autoritats britàniques, en un intent de reivindicar-se i alhora neutralitzar l'escomesa ferotge de la propaganda franquista: la religió, la justícia (amb el sistema penitenciari) i la salvaguarda del patrimoni van dominar l'agenda dels representants de la Generalitat a l'exili britànic. ${ }^{4}$

\footnotetext{
i Epistolari de Josep Cartañà, Bisbe de Girona (1934-1963) (Barcelona: Publicacions de l'Abadia de Montserrat, 200o). Sobre les destruccions del període vegeu Joan BusQuets DaLmaU, «La destrucció d'esglésies a la ciutat de Girona el 1936 i les seves excepcions», dins La Guerra civil a les comarques gironines (1936-1939). Jornades d'estudi commemoratives del cinquantanari, 3 i 4 d'abril de 1986 (Girona: Cercle d'Estudis Històrics i Socials, 1986), 189-222. Josep M. Marquès Planagumà, per la seva banda, hi publica també «Sis diaris i memòries de guerra sacerdotals», ibídem, 71-88.

4 Carles Pi Sunyer i Pere Bosch Gimpera, Informes a les autoritats britàniques, edició a cura de Francesc Vilanova (Barcelona: Fundació Carles Pi i Sunyer, 1992), amb els tres textos que hem esmentat.
}

FRANQUISME \& TRANSICIÓ 4 (2016) ISSN 2014-511X PUNCTUM, UNIVERSITAT OBERTA DE CATALUNYA \& FUNDACIÓ CARLES PII SUNYER 
A les comarques de Girona, com una mica pertot, les accions arbitràries dels comitès, els assassinats de capellans i de gent de dretes, a vegades per raons molt lluny de la política, van marcar uns mesos dramàtics que ens són ben coneguts. Josep Clara en va fer un balanç i una interpretació sintètica molt precisa:

La Guerra Civil va tenir un fort impacte sobre la clerecia diocesana. Els resultats de la persecució religiosa van comportar la mort violenta de 195 capellans, 74 religiosos i tres seminaristes. Hom va perseguir el sacerdot o el religiós pel sol fet de ser-ho, però també per la confusió entre l'Església catòlica i les classes dominants, per l'odi secular a una institució allunyada del poble i contrària als avenços socials promulgats per la República. El nombre de capellans immolats representà el $21 \%$ dels efectius de 1936 , xifra que encara fou superada a Lleida (65\%), Tortosa (61\%), Vic (27\%) i Barcelona (22 \%). Els sacerdots abatuts, més que altes jerarquies de la institució (tampoc cap canonge de la catedral no va ser assassinat), foren els de poble, perquè en el medi rural hi hagué més facilitat per a l'actuació dels grups revolucionaris. ${ }^{5}$

Altrament, la destrucció i la preservació d'obres d'art va esdevenir una eina de propaganda i contrapropaganda durant tota la guerra. ${ }^{6}$ Les dificultats que la pròpia situació va crear al clergat de la diòcesi van propiciar una diàspora en diverses direccions: al territori de l'Espanya franquista i de l'Estat francès, on alguns membres de l'Església de Girona s'erigirien en defensors vigilants de les obres d'art de la Catedral, exhibides a l'exposició de París, o en informadors i propagandistes.7

5 Vegeu el capítol sobre el Bisbat de Girona de Josep Clara, L'Església catalana durant el franquisme (1939-1975). Apunts per a una història, II: Girona, Lleida, Tortosa (Barcelona, Editorial Claret, 2005).

6 Joaquim Nadal Farreras i Gemma Domènech i Casadevall, Patrimoni i Guerra. Girona, 1936-1940 (Ajuntament de Girona, 2015).

7 Josep ClarA, «Unes notes de guerra de Carles de Bolós», dins Miscellània en honor de Josep M. Marquès (Barcelona: Publicacions de l'Abadia de Montserrat, 2010), 501-505. 


\section{Un document significatiu d'un temps}

El manuscrit que es presenta tot seguit, que s'ha editat sense intervenir en el text, va ser redactat pel canonge doctoral Dr. Josep Maria Morera Sabater. ${ }^{8}$ El document pertany a les Actes Capitulars (108, 1935-1940) de l'Arxiu Capitular, conservades a l'Arxiu Diocesà de Girona, i, tot i que no és datat, es troba recollit entre les actes de la sessió capitular de l'1 de maig de 1936 i la de la sessió del 19 de febrer de 1939. Es tracta d'un compendi de pragmatisme restaurador, balanç de la guerra i allegat ideològic, que es complementa i contrasta amb el balanç oficial de totes les destruccions que va sofrir l'Església de Girona, ${ }^{9}$ per bé que se cenyeixi en actes de persecució, empresonament i vexacions, privació del culte, ocupació i incautació de la Catedral, entre els quals no consten, amb una sola excepció, actes de violència extrema, d'acord amb el balanç de Josep Clara esmentat més amunt. El punt de vista catedralici des de la talaia privilegiada de l'acròpolis gironina produeix una visió esbiaixada però subratlla amb èmfasi les implicacions ideològiques del conflicte i les premises de la restauració de la vida eclesial un cop acabada la guerra i restaurada la primacia privilegiada de l’Església i de la religió.

En el seu conjunt, la unitat documental consta de cinc epígrafs (que ocupen les pàgines 45-92), dels quals, però, s'editen només els dos primers: (1) La revolución marxista antiespañola, p. 45-58; (2) Relación bre-

8 Abans de la Guerra Civil el canonge Morera havia format part de la junta de la Delegació a Girona de l'associació Amics de l'Art Vell. Un cop acabada la guerra es va incorporar a la junta de la Comisión Provincial de Monumentos restaurada. Citat com a testimoni, va declarar en l'expedient de depuració de Joan Subias Galter confirmant que el temps que va fer treballs a l'arxiu de la Diputació va rebre'n un bon tracte i va detectar en Subias predisposició per a la salvaguarda del patrimoni. Vegeu, Josep M. Marquès Planagumà, Una historia de la diòcesi de Girona (Barcelona: Publicacions de l'Abadia de Montserrat, 2007); Joaquim Pla I CARGOL, Memoria de la labor realizada por la Comisión Provincial de Monumentos en el año de la Victoria, 1939 (Girona: Dalmau, Carles, Pla, S.A., 1940); Joaquim Pla Cargol, Comisión Provincial de Monumentos de Gerona. Un siglo de actuación (Memoria) (Girona: Imp. Masó, 1949-1950); Joaquim NADAL FAR RERAS, Joan Subias Galter (1897-1984). Dues vides i una guerra (Barcelona: Institut d'Estudis Catalans, 2016).

9 «Sacrificios, ruinas y despojos de la Iglesia gerundense durante el dominio marxista, 19361939", Boletín Oficial Eclesiástico del Obispado de Gerona, núm. extraordinari (nov. 1942). Per a una relació biogràfica detallada dels eclesiàstics assassinats durant la Guerra Civil a les comarques de Girona vegeu Mn. Josep M. BerTa i Cervera, Testimoniatge de Fe $i$ de Fidelitat. Els preveres de la diòcesi de Girona víctimes de la Revolta del 1936 (Girona: Bisbat de Girona, 1991). 
ve de los atropellos sufridos por el clero de la catedral durante la tiranía roja, p. 59-68; (3) Inventario de las pérdidas materiales de la Catedral de Gerona durante el dominio marxista, p. 69-84, que conté, entre altres, els apartats: $(a)$ «Daños en el edificio y en su disposición» («A. Exterior del edificio», «B. Interior del edificio»), (b) «Daños en las capillas y altares», (c) «Imágenes de santos especialmente destinadas al culto, destruídas», $(d)$ «érdidas de ropas, ornamentos, vasos sagrados y accesorios», $(e)$ «Objetos de culto y de valor artístico, llevados a París en 1937 y no recuperados todavía», $(f)$ «Objetos de valor artístico, sacados de la Catedral, ahora recuperados», $(g)$ «Pérdidas de alhajas, objetos de culto y de arte, pinturas»; (4) Pérdidas de joyas, alhajas, vajillas de plata y objetos preciosos procedentes de Casa Carles, donados en 10 Mayo 1929, p. 85-88, i (5) Valoración de las pérdidas y destrucciones causadas por los rojos en la Catedral de Gerona, p. 89-92. En aquest darrer epígraf, per posar un exemple, la valoració dels danys ascendeix a 1.024.720 pessetes, una quantitat sobre la base de la qual es negociarien les aportacions que havia de fer el nou règim com a reparació dels danys de guerra. L'Església es preparava així per a la reconstrucció material, per a la recuperació de l'esplendor del culte i de les obres d'art desplaçades i disperses, i per a la restitució del cerimonial més tradicional en què s'expressava la constant interdependència entre les autoritats civils i les eclesiàstiques. La prolixitat i el grau de precisió dels apartats que no es publiquen ara és, doncs, extrema, de manera que resulten útils per entendre l'abast de les pèrdues i destruccions, sobretot de béns mobles. En el seu conjunt aquestes destruccions no desmentirien que el patrimoni catedralici es mantingués força íntegre; canviés de naturalesa en els anys de la guerra amb l'aspiració materialitzada d'esdevenir un gran museu d'art, sense obrir-se al públic; es traslladés parcialment a França amb les peces més notables per integrar-se a l'exposició d'art medieval català de París de 1937, i altrament patís també els efectes destructius de l'aviació franquista i els seus bombardeigs.

En el primer apartat dels dos que s'editen, La revolución marxista antiespañola de 1939, el Canonge Josep Morera se sent cridat a fer una crònica dels anys de la persecució religiosa, la destrucció de temples i obres d'art, la persecució i l'assassinat de religiosos, la clandestinitat de la vida religiosa i les circumstàncies personals, en els anys de la revolució, de la 
vida de Canonges i Beneficiats. Abunden les dades i les dates concretes, com també els adjectius i les hipèrboles en relació amb el context. El document és ple de referències adients que permet traçar el marc ideològic de la represa religiosa, la identificació de l'Església amb el franquisme i com es va forjar el nacionalcatolicisme. És, en definitiva, el viu reflex de la represa de la vida de la canònica. Amb ella, les Actes Capitulars recuperen el fil després de més de dos anys i mig en blanc, quan ja havien passat els anys de la Guerra Civil amb la interrupció del culte, s'havia transformat la Catedral i el Palau Episcopal en els "museus del poble", s'havien installat les obres d'art recollides a les Sales Capitulars (sense que mai s'obrissin, però, al públic), i s'havia traslladat a París un bon nombre d'obres d'art de l'Església de Girona. ${ }^{10}$ En el segon, en canvi, Relación breve de los atropellos sufridos por el clero de la Catedral durante la tiranía roja, s'hi relacionen cas a cas les peripècies de canonges i beneficiats, i l'assassinat de mossèn Joan Guix, el 14 d'agost de $1936 .^{11}$

10 Sobre la persecució religiosa durant la guerra, vegeu l'article de Joan BuSQuETS DALMAU, «La persecució religiosa al Bisbat de Girona», Revista de Girona 116 (1986): 223-232. I sobre la situació del Capítol abans de la Guerra Civil, Josep Clara, «El Capítol de Girona i la Segona República», Anuari 1988 de la Societat d'Estudis d'Història Eclesiàstica Moderna i Contemporània de Catalunya (1990): 59-73.

11 Vegeu Josep Clara, «El Capítol de la catedral de Girona i la Guerra Civil», Revista de Girona 183 (1997): 64-67, on recull part de la informació del document que publiquem referint-se exclusivament als canonges. En aquest article subratlla que la major part dels clergues immolats correspongueren a les àrees rurals i que en termes relatius les baixes de capellans de la ciutat de Girona per la violència dels comitès fou menor. 


\section{La revolución marxista antiespañola de 1936}

Las actas capitulares sufren, al llegar aquí, una brusca interrupción de treintiún meses que es preciso explicar para perpetua memoria. De muchos siglos a esta parte no había sufrido la Iglesia española tan dura persecución, ni había experimentado tan duras convulsiones nuestra patria.

La malhadada república que, nacida de imbendecibles uniones, sorprendió a los buenos españoles el 14 de abril de 1931, y antes del mes daba testimonio de sí en la vandálica quema de iglesias y conventos de Madrid y de otras ciudades; después de haber pasado por la repugnante y criminal revolución de octubre de 1934, nos trajo las fatídicas elecciones de febrero de 1936 que fueron el digno colofón de su nefasta obra.

Con miras a ellas formóse el infausto "frente popular", amalgama de todos los partidos de izquierda, desde los que alardeaban de cultos y habían tenido responsabilidades de gobierno hasta los más indeseables afiliados al comunismo y anarquismo. La persecución que hacía casi un quinquenio se llevaba a cabo desde el reducto de la legislación contra Jesucristo y su Iglesia, contra el culto religioso y sus ministros, llegada en muchos casos hasta lo más íntimo del hogar y los sentimientos católicos de los ciudadanos, y el libertinaje que con ella cundía, engrosaron esos partidos, algunos de los cuales se imponían a las masas con la coacción o las peores propagandas demagógicas. Con tales medios de captación y las acostumbradas falsedades, violencias y atropellos, logró su triunfo el frente popular, y lo administró de repugnante manera. Los asesinatos cometidos con absoluta impunidad ensangrentaron las calles de Madrid y otras ciudades.

Ese ambiente de crimen motivó las naturales reacciones.

El día 13 de julio caía vilmente asesinado el Sr. Calvo Sotelo, político integérrimo y capacitado economista, quien en la flor de la edad era una bella esperanza de la patria. La noticia del hecho levantó una ola de indignación en todas las conciencias honradas; indignación que subió de punto cuando en la frase del funesto Casares Quiroga, entonces Jefe del Gobierno, de 
que "éste se sentía beligerante" pronunciada en la sesión de la Comisión permanente de las Cortes, se entrevió la culpabilidad de las autoridades.

La gravedad de esta situación hizo presagiar acontecimientos que no tardaron en presentarse. Un puñado de egregios y pundonorosos militares decidió cerrar la vergonzosa etapa de inmoralidades, claudicaciones y crímenes. Así comenzó el glorioso Movimiento Nacional, del cual no es nuestro intento escribir la historia.

El 19 de julio, secundándolo el mando militar de esta plaza y provincia, fue proclamado aquí el estado de guerra. El recuerdo de las pocas horas que la Generalidad pudo mantener la rebelión contra el Gobierno constituido en octubre del 1934, hizo ver en esa proclamación el remedio pronto y eficaz; pero la Providencia permitió, en sus inexcrutables designios, que tal remedio fracasara. Era muy hondo el mal, y se había de medir toda la profundidad del abismo de donde partía.

Durante toda la mañana del domingo, dia 19, la radio difundió alarmantes noticias de la resistencia que encontraba en Barcelona el Movimiento salvador. En nuestra ciudad los centros políticos de izquierda no fueron clausurados, viéndose muy concurridos desde primera hora de la tarde, como igualmente los cafés y las organizaciones sindicales. Alarmado por la pavorosa perspectiva de un posible fracaso, el que estas líneas escribe, fuése aquella tarde a la Catedral, lleno el ánimo de preocupaciones. Un muchacho que allí había contó que había estado en el Centro Republicano de la calle del Carmen cuyos concurrentes, muy excitados, no cesaban de culpar a la Iglesia, amenazando con destruir y quemar los templos y atropellar a los sacerdotes. No me impresionó la relación del muchacho, que de momento juzgué ser la repetición de la frase simplista que achaca de todo la culpa al clero. Pero cuando los sucesos siguientes acusaron una barbarie y maldad no imaginadas, se pudo deducir de dónde partía en esta ciudad el impulso inicial de ejecución de un plan, que siendo general y uniforme, había de ser premeditado.

La tropa que en la mañana del 19 se había distribuido por las calles de la ciudad, guardaba por la tarde una pasividad expectante. A las nueve se retiró, conocedora por la radio de su licenciamiento. A medida que se 
retraía la fuerza pública, invadía sus atribuciones la chusma, que, autorizada para armarse, sacó las armas de los cuarteles. ${ }^{12}$

Las sindicales obreras se agitaban en un ambiente de revuelta, caldeado por las propagandas subversivas. Existía una infinidad de partidos, centros, comités, organismos y juntas que actuaban en la sombra, y una notable infiltración de gente advenediza, ocupada a fuer de sin-trabajo, en obras improvisadas, o dedicada a la mendicidad y a la vagancia: tal suele ser la plaga precursora de los grandes trastornos sociales. En dichos antros y con tan válida cooperación se fraguaron los primeros núcleos revolucionarios, que en la noche del 19 al 20 de julio asaltaron los desiertos centros políticos de derecha, destrozando y quemando el mobiliario; asalto extendido luego a las organizaciones católicas, templos, conventos y casas particulares de honradísimos ciudadanos.

El convento de Santa María de Cadins, de religiosas del Císter llamadas vulgarmente "las Bernardas" fue el primero en sufrir la ola de destrucción, ${ }^{13}$ como asimismo las iglesias del Sagrado Corazón y del Mercadal y el centro de Acción Católica de la noble casa de Carles. De allí se propagó a las demás iglesias y casas religiosas sin perdonar los venerables edificios de la Catedral y San Félix. ${ }^{14}$ Unos guardias del cuerpo de Asalto daban vergonzosa escolta a esa turba de bandidos formada por mozalbetes, indeseables y mujerzuelas. Como suele ocurrir en tales ca-

12 Les circumstàncies de les primeres hores de la guerra a la ciutat de Girona han estat tractades des de diversos angles per testimonis directes. En el volum collectiu La Guerra Civil a les comarques gironines (1936-1939) (Girona: Quaderns del Cercle, 1986) s'hi publiquen els records directes d'Antònia Adroher, «Records de joventut: la República i la Guerra Civil» (p. 5-22) i de Miquel Gayolà, «Records del 18 i 19 de juliol» (p. 43-48); Josep M. Marquès Planagumà presenta, per la seva banda, les aportacions de «Sis diaris i memòries de guerra sacerdotals» (p. 71-88), un article on tracta de les memòries de Mn. Josep Casanovas i Genover (L'Armentera, 1884 - Girona, 1965), Mn. Joan Planella i Colomer (Mieres, 1882 - Girona, 1978), el Dr. Damià Estela i Molinet (Besalú, 1904 - Girona, 1979), Mn. Ferran Forns i Navarro (Girona, 1897-1970), Mn. Joan Coll i Taberner (Santa Coloma de Farners, 1905-1978) i Mn. Esteve Jou i Parés (Girona, 1897-1985). El perfil biogràfic d’Antònia Adroher es repeteix amb variacions que no alteren el contingut al capítol d'Antònia ADROHER i Carmel RosA, «Per què vam anar a l'exili. Breus biografíes familiars i polítiques de l'Antònia i en Carmel», La llavor dels somnis (Girona: CCG Edicions, 2001).

13 Joaquim NADAL I FARRERAS, «El convent de les Bernardes: Exclaustració i restitució (19361939)», Annals de l'Institut d'Estudis Gironins 57 (2016): 329-372.

14 Joan Busquets Dalmau, «La destrucció d'esglésies a la ciutat de Girona el 1936 i les seves excepcions», dins La Guerra Civil a les comarques gironines..., 189-222. 
sos, un corto número de granujas, engrosado con gentuza inconsciente u osada se impuso a la gran masa de ciudadanos indefensos y pacíficos cuando la fuerza pública dejó de ser garantía del derecho ofreciendo ampara a la violencia. La revolución había triunfado.

La chusma empuñaba las armas y patrullaba por las calles ante la general consternación de la gente de orden. Las pobres religiosas, echadas de sus conventos al ser éstos saqueados, se acogían al caritativo hospedaje particular. Los sacerdotes, de momento, no fuimos molestados, si bien eran pocos los que a la sazón salieron de su domicilio, vestidos de paisano. Pronto comenzó la repugnante cadena de saqueos, robos y asesinatos que caracterizó la segunda mitad del año 1936, cuyos días y horas se hacían interminables.

Entre tanto el Prelado había salido del palacio episcopal, logrando poco después pasar la frontera. ${ }^{15}$ Milicianos y guardias de Asalto, a las órdenes de la Comisaría de la Generalidad, registraban minuciosamente las dependencias y oficinas del palacio, sacando de él muebles, ropas, ornamentos y enseres, y apoderándose del numerario y fondos de la diócesis custodiados en la Caja diocesana. La radio local difundía noticias de "tranquilidad", mientras el ánimo de los honrados ciudadanos era presa de mortal zozobra, y subvertido todo sentido moral, jactóse de ese robo cual de un acto de justicia.

Las personas que antes del movimiento militar ejercían cargos de gobierno, volvieron a sus despachos desde el día 20, pero difirieron muchos días la toma "oficial" de posesión para dar visos de verosimilitud a lo que tanto se propaló después: que los desmanes eran debidos a un ímpetu irreprimible del pueblo. Actuaron enseguida los comités funestísimos, mesclándose y actuando las llamadas “autoridades" con ellos.

En la tarde del domingo 26 de julio el titulado Comité de Justicia, capitaneado por un tal Juanola de oficio albañil, fue a apoderarse del tesoro de esta santa Iglesia. Hiciéronse abrir las puertas de la Caja de hierro donde se guardaban las alhajas; y así se adueñaron de todas las dependencias

15 L'informe del Dr. Morera omet la decisiva intervenció del conseller Ventura Gassol per facilitar la sortida del país del Dr. Cartañà. Sobre la sortida d'Espanya del Bisbe Cartañà, les diverses versions que han circulat i la reconstrucció dels fets vegeu Clara, El Bisbe de Girona..., 30-38. 
de la Catedral, Archivo, Salas Capitulares, etc. Cuando de alguna puerta o cerradura no estaba a mano la llave, era violentamente descerrajada o rota.

Inmediatamente se recogió el botín, llevándose los bandidos de "Justicia” gran cantidad de objetos de plata. Entonces fue fundida la estatua de plata de la Inmaculada Concepción, egregio donativo del ilustre Obispo Don Tomás Sivilla a su Iglesia. Reproducía una de las imágenes celebérrimas de Murillo, y pesaba noventinueve kilogramos. Otros objetos de gran valor, como la urna de plata del Monumento, artística obra de un notable platero gerundense, fueron destruidos y rotos pero no robados.

El mobiliario litúrgico del templo fue pagando tributo al espíritu de destrucción dominante; y si pudo sobrevivir fue a costa de mil peripecias. Lo propio sucedió con los altares: en gran número destruidos, los que se pudieron salvar ostentan notables desperfectos. ¡Qué profanaciones han debido soportar que les causaran tantas y tales heridas! El pavimento basilical vio levantadas entre horrendas blasfemias no pocas de sus losas sepulcrales, y el acerado pico dio paso al soez insulto y a la sacrílega violación del piadoso respeto hacia los muertos. No pudieron librarse de esta prueba de barbarie y de incivilidad los restos venerandos de muy insignes varones, cuando el glorioso sepulcro del mártir San Narciso, patrono de la ciudad, y su sagrado cuerpo han sido objeto de abominables sacrilegios.

Por este tiempo el ángel de bronce que remata la torre del templo catedralicio, mostraba cabizbajo la fatídica bandera de la F.A.I. (federación anarquista ibérica); y bajo este infortunado signo hubimos de contemplar como se descolgaban y hacían pedazos las seculares campanas, compañeras de penas y glorias de la bienamada ciudad que ahora las perdía para siempre... Después fue instalado en el templo vacío de tantos tesoros de arte y de piedad un vergonzante "Museo del pueblo", cuyas puertas el pueblo no vería abiertas jamás. En nuestras iglesias tan deplorablemente tratadas el verdadero y muy valioso museo era el que había desaparecido, no el que con míseros despojos se pretendía ahora constituir. ${ }^{16}$

16 Els testimonis directes, els balanços i informes, i les fotografies de què disposem desmenteixen la contundència d'aquestes afirmacions. La Comissió del Patrimoni Artístic i Arqueològic va vetllar pel patrimoni conservat i va tenir cura de desplegar un projecte museogràfic ambiciós i amb molt de contingut. Els avatars de la guerra n'impediren la culminació. El que sembla segur és que a les Sales Capitulars s'hi van disposar les peces més notables del patrimoni de la Catedral i de la diò- 
Pero al sectarismo que había desencadenado una tremenda persecución religiosa, cual no se había conocido de muchos siglos acá en nuestra España, no le bastaba echar del templo a los fieles y sacerdotes, los objetos del culto, las imágenes de los Santos y la Majestad de Dios; las órdenes procedentes del comunismo ruso y de las logias masónicas eran terminantes: se imponía perseguir cualquiera manifestación de catolicismo aún en la intimidad de las familias, despojar a los ministros del culto de sus bienes y negar toda seguridad a sus personas; y así se ejecutó prontamente. Un decreto del 6 de agosto disponía la incautación de los bienes de la Iglesia y del clero; así se cohonestó un inmenso latrocinio del que fuimos víctimas. Otro decreto emanado de no sé dónde y publicado por la radio entre amenazas de registros y graves sanciones, prohibía la tenencia de imágenes y objetos religiosos, del culto católico. Era natural que muchas personas piadosas y sacerdotes, por el sólo hecho de serlo, se vieran atropellados de mil modos. Estábamos proscritos, y como tales podíamos ser impunemente asesinados. Los más fuimos robados y conducidos a la cárcel, quedando incierto si ese trato recibido era para salvarnos la vida según decían los que contribuyeron a darlo, o bien para tenernos a mano el día que se antojara efectuar una hecatombe, como sospecharon muchos. Sea de ello lo que fuere, es lo cierto que del clero catedral estuvieron presos los Sres Deán, Chantre, Maestrescuela, Doctoral, Penitenciario, Canadell y Lectoral de los Canónigos; y los Rdos Poves, Trias, Itchart, Durán, Doménech, Morell, Aluart, Perramón y Bojons de los Beneficiados. El Rdo. Don Juan Guix, Tenor, ejemplarísimo y muy virtuoso sacerdote, fue asesinado con tres padres de la Compañía de Jesús, primicias los cuatro de los mártires sacerdotales de la presente ciudad.

El día que ingresaron en la cárcel y preventorio judicial la mayor parte de los sacerdotes referidos, una alarma de trágicas consecuencias dejó en ellos un imborrable recuerdo. Se habló de un bombardeo de Rosas. Al parecer, un buque de guerra disparó en aguas de Rosas contra una barcaza cargada de armas, hundiéndola. La noticia cundió rápidamente, difun-

cesi, que no eren pas justament «míseros despojos». Sobre aquests aspectes vegeu alguns dels textos de Joan Subias Galter transcrits a NADAL FArReras, Joan Subias Galter..., i també les actes de la Comissió publicades per NAdal FARreras i Domènech CASADEvall, Patrimoni i Guerra... 
dida desde Barcelona por la radio. Sin duda obedeciendo a una consigna, mientras la gente adicta al movimiento nacional creía ver un síntoma de la proximidad de su dichosa liberación, los que se decían antifascistas pusiéronse en agitación violenta. Mientras una imponente caravana de coches y camiones emprendía el camino de Rosas, algunos se dedicaron a la "caza del cura", llevando buen número de ellos a la cárcel. Juntamente fueron detendios otros beneméritos ciudadanos. El ambiente estaba cargado de amenazas y de los más siniestros rumores. Hacia la media noche un grupo de milicianos armados capitaneados por los más siniestros sanguinarios verdugos, se dirigió a determinada celda del preventorio. No logrando de momento abrir la puerta, disparó desde la mirilla, hiriendo y matando a las pobres víctimas. En la celda contigua ocurrió lo propio. Una consternación general se apoderó de la población cautiva, mientras ocho excelentes compañeros caían asesinados en su mismo encierro. Dos días más tarde eran sacados de la cárcel y vilmente asesinados otros doce egregios ciudadanos. Esos botones de muestra revelarán al lector como vivíamos entonces. ${ }^{17}$

$\mathrm{Ni}$ era mejor la suerte de los que continuaban en sus domicilios, en fondas, o en casas particulares. Del domicilio conocido podían ser sacados los individuos a cualquier hora del día o de la noche; y para vivir en otras partes necesitábase un permiso de los Comités que muchas veces sirvió de guía para dar más fácilmente con las víctimas. Habiendo sido inmolados en la diócesis cerca de doscientos sacerdotes y religiosos y un muy crecido número de seglares de toda edad, sexo y condición social, desde el ilustre hombre de carrera y el opulento señor, hasta el humilde obrero y el modesto funcionario, algunos de los cuales sufrieron indecibles torturas, ni una sola responsabilidad se exigió por asesinato; ni la

17 Sobre la destrucció i els assassinats a la rereguarda a la província de Girona, Pere Joan Sureda Canals ha publicat tres llibres voluminosos, i en prepara el quart, escrits amb to vindicatiu i acusador. El detonant de tots ells és la consciència de l'assassinat del seu pare Pere Sureda Corominas (Salt, 1904 - Orriols, 1936). Més enllà de la fortíssima càrrega de subjectivisme, cal dir que els volums contenen moltíssima informació, una mica desordenada però gairebé sempre contrastada, que l'autor transforma en una acusació contra les autoritats republicanes i la Generalitat, a les quals acusa de passivitat i consentiment. Vegeu Del bressol a la cuneta. Pere Sureda Corominas, Salt, 1904 - Orriols, 1936 (Girona: CCG Edicions, 2009); Girona sota els Comitès 20 de juliol - 15 d'octubre de 1936. Homenatge a Girona, I (Girona: Curbet edicions, 2013) i Girona sota el Consell Municipal Revolucionari, 16 d'octubre de 1936 - 30 de juny de 1937. Homenatge a Girona, II (Girona: Curbet edicions, 2016). El darrer volum tractarà dels darrers mesos de 1936 fins al final de la Guerra Civil. 
prensa o la radio dio jamás de ello una noticia, ni siquiera se toleró durante mucho tiempo que vistieran de luto los familiares. Y con el mayor descaro, cinismo y mala fe en desvergonzadas propagandas que daban la vuelta al mundo se ponderaba la legitimidad del gobierno, cómplice sino autor de tantos crímenes, la legalidad, el orden, la justicia y la libertad, etc. No conocemos un período de la historia en que la abyección y el envilecimiento moral hayan llegado a tales términos. Esa fue "la república de la farsa" amasada en "lágrimas, sangre y lodo".

El 14 de noviembre los sacerdotes detenidos en el Seminario (preventorio judicial), mayores de 65 años fueron trasladados al Asilo de Ancianos de las Hermanitas de los Pobres. Poco después se vio el porqué de esa medida; pues a los cinco días eran sometidos los demás a trabajos forzados. En esta condición hubieron de trabajar en adaptar para garaje la iglesia de Ntra Sra del Carmen. Más tarde fue "la brigada" al Colegio de los Salesianos, al Hospital y a otras obras. Un grupo fue encargado del arreglo y ordenación del Archivo de la Diputación Provincial, trabajo encomendado a quien lo reseña. En el transcurso de los meses desde este lugar se pudieron prestar buenos servicios en favor de los compañeros. Varios milicianos armados nos acompañaban y vigilaban. Parece tenían orden de disparar si alguien se insubordinaba; pero recordando a los mártires de las antiguas persecuciones, no solo se tomó esa medida humillante con unánime resignación, sino aún, por parte de muchos, con ejemplar alegría. Servíamos a Dios en el trabajo.

Esta medida que tocando al clero fue peculiar de Gerona, atribuyóse a una especie de transacción entre gobernantes y sindicales. Dijose que intentaban unos "la supresión" de los curas, cuando sugirieron otros el someterlos a trabajos. Comoquiera que fuese, la resolución, solemnemente anunciada por la radio local, fue del agrado del populacho, que en su simplismo habitual considera holgazán a quien no trabaja en obras serviles, y fácilmente toma por regla general la primera excepción que se le ofrece. De la humillante medida muy pronto cogimos un primer fruto: la mayor consideración que ganó el clero "trabajador" en el concepto de la gente inculta que nos rodeaba por todas partes.

A los afectados por esa disposición acarreábales molestias la publicidad que dio a tal medida carácter de espectáculo; la índole del trabajo, en 
un templo ya profanado que se iba destinando a usos civiles; la compañía de gitanos, seguramente escogida para mayor ignominia; la ingrata vigilancia de los milicianos y su lenguaje soez y grosero; y la imposición de trabajar en días festivos. Pasados los primeros meses del 1937 asumieron los guardias de Asalto el encargo de acompañarnos, lo que constituyó un notable alivio.

Pero el mejor reactivo del ánimo oprimido en la prisión suministrábanlo las prácticas religiosas y las halagüeñas noticias que difundía la radio desde la zona nacional.

Nuestra santa religión, proscrita en todas sus manifestaciones, seguía señoreando los espíritus con mayor fuerza que nunca, por ser el camino de la tribulación el que nos acerca más a Dios. Ya desde los primeros días, seglares y sacerdotes detenidos acudieron al rezo del santo rosario como a un manantial de consuelos: práctica que, burlando la importante vigilancia, unió muchas veces al día en el fervor de la plegaria a los que había juntado la persecución y el infortunio. A esta devoción sumáronse otras, cuando las circunstancias parecieron favorables. Incluso se pudieron organizar con el más lisonjero éxito, pláticas, conferencias, cursillos de religión, ejercicios espirituales, etc. Los actos más emocionantes fueron las Comuniones celebradas bajo el dominio del terror, y las confesiones de las víctimas que presentían su holocausto. Asi debieron verificarse tales prácticas en las catacumbas de Roma. No era posible mayor fervor, mayor recogimiento, ni mayor pobreza.

Las noticias de la radio nacional, sobretodo las alentadoras charlas del insigne General Queipo del Llano entraban a hurtadillas en la cárcel, corrían de boca en boca, y a los pocos minutos tanto se habían transformado, que resultaba imposible separar lo auténtico de la accesión. Apenas apuntaba la ofensiva, dábamos por conquistada la totalidad del territorio. Pero en este punto no había gran diferencia entre prisioneros y libres, agitados por unos mismos anhelos, aturdidos por idénticos atropellos y animados por iguales esperanzas.

Los afortunados radio-oyentes, habiéndose hecho menos difícil la ansiada comunicación con los familiares, nos aseguraban que pronto concluiría el cautiverio. Eran las fiestas de Navidad de 1936, que, según la práctica de la incultura y sectarismo rusos, los sacerdotes las hubimos 
de pasar en el trabajo de ocho horas diarias. Una gestión pidiendo fiesta para la de la Inmaculada Concepción no dio resultado alguno. Así vivíamos forjándonos ilusiones, que no dudábamos se habían de trocar en realidad, cuando la fiesta de Reyes trajo a la cárcel un auto de procesamiento. Afectaba a más de cincuenta sacerdotes del preventorio, la cárcel y el Asilo de Ancianos. Algunos, sin embargo, no fuimos incluidos en él, sin que sepamos la causa. Confiamos una vez más a la Providencia de Dios el velar por la inocencia perseguida, y tras contínuos señalamientos y dilaciones se llegó al sobreseimiento de 18 de julio. Mas no triunfó el buen derecho, porqué los declarados sin motivo de detención continuaron allí en calidad de presos gubernativos.

Los afiliados de la F.A.I. habían intentado una revuelta a primeros de mayo, la cual fue sofocada en Barcelona. Aquí hubo momentos de agitación sin consecuencias. En alguna población de la provincia ciertas personas fueron sacadas de sus casas y poco después se encontraron muertas cerca de la carretera de Cadaqués. Ello hizo revivir las repugnantes escenas de terror de los primeros meses, que ya parecían superadas. Siendo alguna de las víctimas de izquierda republicana, el hecho criminal se llamó por su verdadero nombre: asesinato. De aquí que ingresaran en la prisión algunos comités más destacados por sus crímenes, que aparte de esto quedarían impunes como antes. Con ello la cárcel ya no albergó tan solo gente honrada; lo que impuso mayor cautela en conversaciones y prácticas piadosas. Abortado ese conato de rebelión, de hecho más aparatoso que temible, los "milicianos" fueron definitivamente obligados a ir al frente o dejar las armas, con lo cual quedó suprimida una institución que vivió y murió llena de oprobio.

Por ese tiempo hacen su entrada en el preventorio los primeros grupos de jóvenes que al intentar el paso de la frontera tuvieron la suerte adversa.

El mes de julio de 1937 trae a los eclesiásticos detenidos la cesación de trabajos forzados y las primeras libertades. Las inaugura el 22 el autor delas presentes notas, y otros le siguen luego entre ellos los siete sacerdotes no comprendidos en el auto de procesamiento. A poco cuatro son puestos en la calle mediante un simulacro de juicio. Y continúan en calidad de presos gubernativos los que tienen sobreseida la causa. El grupo que trabaja 
en el Archivo Provincial prosigue voluntariamente su tarea. El Sr Doctoral no abandona a estos dignos compañeros de sacerdocio, y a pesar de su enfermedad, está cada día con ellos, anhelando su libertad. Esta se va alcanzando poco a poco, siendo excarcelados todos los "trabajadores" de dicha dependencia el dia 23 de noviembre. Por azares de la fortuna, allí se alivia la situación de muchos, se facilita su comunicación con los familiares, y es la puerta de salida de la prisión para la mayor parte.

El 6 de enero de 1938 son puestos en libertad los diez y nueve que alberga todavía el preventorio y todos los del Asilo de Ancianos, quienes sin embargo, careciendo de todo, se acogen de nuevo, salvo unos pocos, a la generosa hospitalidad del benéfico establecimiento. A los no privilegiados de la población civil falta comida, pan, jabón, grasa, combustible, etc. Cuantas medidas se toman lejos de remediar esta suituación la agudizan más poniendo al descubierto la desigualdad e injusticia del régimen que padecemos. Nada les falta a ciertos elementos dirigentes o indeseables, ni a los múltiples agentes de requisas. En medio del malestar debido a estas circunstancias, hace su tétrica aparición el terrible S.I.M (servicio información militar), con sus bárbaras "chekas" e inauditas torturas.

La persecución religiosa al principio tan extensa y cruel, cede su puesto a la que se desencadenó algunos meses ha contra los "fugitivos y emboscados". A esos jóvenes les acosan numerosos agentes de pesquisas; y habidos, entran en la prisión, cuyos ámbitos adquieren mayor dureza y severidad. Por los no habidos son atropellados los familiares, si son elementos derechistas. En cambio, para los del frente popular se crean cargos, cuerpos especiales y destinos, "enchufes" y exenciones de todas clases. Llega un momento que la fecunda inventiva de los que tienen en sus manos los resortes del poder queda exhausta y agotada.

Al constatar que lo tocante a la religión tan duramente proscrita no interesa ya a los cuerpos de vigilancia, se organiza furtivamente el culto en domicilios particulares. Con todo disimulo y discreción celebramos reuniones los Capitulares y párrocos, remediando abusos y proveyendo a las difíciles circunstancias.

Repasamos el deplorable estado de los templos: el del Carmen hecho garaje y dependencia de la fuerza pública; destruidos los del Mercadal y Bernardas; el del Sagrado Corazón convertido en almacén, la iglesia de 
San Félix, no obstante la etiqueta sarcástica de "monumento nacional", despojado de todo y lleno de carricoches destrozados. La Catedral, sacrílegamente profanada, ha perdido su valiosísimo tesoro. En 1937 fueron llevados a París el tapiz de la Creación, el retablo y baldaquino de plata repujada con esmaltes y pedrería, la estatua de Carlomagno, las tapas de evangeliarios, dos de las cruces del altar mayor, etc. En 1938 trasladábase a un depósito rural lo mejor de lo que quedaba: la cruz catedralicia de oro y perlas, las arquetas árabes, la Biblia, el Apocalipsis, estatuas y pinturas. ¿Volvería todo ello a recobrarse?...

En la guerra las esforzadas huestes nacionales recorren las sendas de la victoria. A las tomas de Málaga, Bilbao, Santander y Asturias que llenan el año 1937, tras las cruentas vicisitudes de Teruel y facilitada por ellas, se suma en 1938 la totalidad de Aragón y margen derecha del Ebro hasta el mar, en la provincia de Castellón de la Plana. Las ofensivas que proyectan y efectúan los mandos rojos son sangrientos fracasos que abren la puerta a singulares avances. La "república de Negrín" como solemos llamarla, después de partirla en dos el certero golpe de la espada victoriosa del Caudillo, sigue coleando irremisiblemente condenada a muerte, como la culebra que divide en dos pedazos el azadón del labrador. El gran número de fuerzas internacionales acumuladas, el formidable acopio de material bélico, los refinados procedimientos de crueldad con que se obliga a las muchas quintas movilizadas a no cejar en la lucha y la incansable propaganda para lograr nuevos refuerzos, no logran sino prolongar por algún tiempo la agonía.

Para la propaganda se echa mano de todo: hasta se invoca ; la tolerancia religiosaj. Humeantes todavía las cenizas de iglesias y altares, a la vista de la imponente catástrofe que ha asolado nuestros templos, apelar a ese resorte es el colmo del cinismo y desaprensión; creerlo es la patente de mala voluntad o de inconsciencia...

Y sin embargo veíamos con estupor que la propaganda hacía mella en ciertos medios extranjeros que aceptaban sus tendencias sin reparo. En este ambiente de derrota cubierta de palabrería nació el fugaz "Comisariado de Cultos”. El texto de su institución se dio íntegro a la prensa antes de publicarlo la Gaceta, en 9 diciembre. Intranquilidad causónos la medida, que podía incoar una lamentable captación, más funesta que la persecución descubierta. 
La amorosa Providencia vino pronto en nuestro auxilio, comenzando la deseada ofensiva que devolvía a Cataluña su libertad. De las márgenes sangrientas del Ebro y del Segre, alegrando nuestras tristes Navidades, nos llegaba a un mismo tiempo el rumor jubiloso del avance y el discorde clamor de la desbandada. La prensa, rebosante de parcialidad, desmentía la farsa de los amañados partes oficiales, del Ministerio de Defensa, que mejor se llamara de preparación de la huida; pues los voceros de la sobada "resistencia” llenaban rápidamente de botín de rapiña su equipaje. Los periódicos de acá, ahitos de infligir serio quebranto al enemigo, dejaron de publicarse en la segunda quincena de enero. Dirigentes y comprometidos huyeron en tropel, formando caravana interminable, y proclamando en el vértigo de la huida, que las horas rojas de la capital estaban tocando a su término.

Cúpole a Gerona, sin advertirlo, el triste sino de ser efímera sede ministerial de un régimen que se ahogaba en su propio vilipendio. El dia 26 de enero, Barcelona, rebosante de júbilo, abría los brazos al ejército libertador. Su redención era el preludio de la nuestra, si bien nos separaban de ella duras jornadas. El dia 28 sufrióse aquí un serio bombardeo de aviación, otros dos el 29 y nueve el primero de febrero. ${ }^{18}$ Una bomba de ese penúltimo dia hizo blanco en el tejado de la Catedral, destrozándolo y derribando algunos metros de bóveda. En esos angustiosos trances hubo víctimas y ruinas. Pero los más lamentables, que no tienen calificativo adecuado, por no ser azares de la guerra sino actos de mano criminal, fueron la estela de incendios, destrucción y asesinatos que dejó el vil Líster en su cobarde fuga.

Las columnas de humo y llamas salidas de los edificios incendiados advirtieron al ejército victorioso de la apremiante necesidad de su presencia; y tras una preparación artillera de tres horas entró gloriosamente al mediodía del sábado 4 de febrero.

Al siguiente día un gentío inmenso oyó Misa en la plaza de la Catedral.

18 Sobre els bombardeigs de l'aviació franquista a Girona, vegeu Jaume Prat i Jordi Pericot, Bombes sobre Girona. La defensa passiva a la guerra civil (1936-1939): barricades, trinxeres i refugis antiaeris (Girona: Ajuntament, 2012). De la bomba del 29 de gener que va causar desperfectes a la Catedral, vegeu, concretament, el comentari de la pàgina 38: «una de les bombes causà un forat de $3 \mathrm{~m}$ de diàmetre sobre la volta gòtica i diverses destrosses». 
II

\section{Relación breve de los atropellos sufridos por el clero de la Catedral durante la tiranía roja}

Don Antonio Naranjo y Luque, de 75 años de edad, Deán desde el año 1913. El día 26 de julio de 1936 sufrió un primer registro y despojo de bienes, al que siguieron otras impertinentes visitas e interrogatorios hechos por gente armada los Comités. El 24 de Septiembre fue detenido y llevado al preventorio judicial, sito en el Seminario, donde estuvo hasta el 14 de Noviembre. En esta fecha fue trasladado al Asilo de ancianos de las Hermanitas de los Pobres, en calidad de detenido. El dia 6 de enero de 1938 fue puesto en libertad, continuando en el benéfico establecimiento hasta la liberación de la ciudad, que tuvo lugar el 4 de febrero de 1939.

Don Antonio Vilaplana y Forcada, de [en blanc] años de edad, Arcipreste desde el año 192[en blanc]. Temiendo fundadamente por su seguridad personal desde los comienzos de la revolución vivió oculto en casa de unos amigos. Al efectuarse, entre amenazas, un serio registro en su domicilio, decidió abandonar la ciudad, trasladándose sigilosamente a Barcelona. En su casa solariega de Vich habían sido asesinados un cuñado y dos hermanos suyos. Poco después se fue al extranjero, fijando su residencia en Roma, ocupado en el Secretariado internacional de Acción Católica.

Don Pedro Iglesias y Guardia, de 7[en blanc] años de edad, Canónigo desde 1898 y Arcediano desde 1924. Vivía en el Seminario como Rector del mismo. El dia 21 de julio de 1936, ante los insistentes rumores de que las turbas querían incendiar ese establecimiento, fue a pedir auxilio al Gobierno Civil, recibiendo la contestación de que no podían responder del orden; pero que, dada la proximidad del edificio, avisarían en caso de peligro. El 22 por la tarde recibieron orden de abandonar esta residencia, hospedándose en una casa particular hasta el 8 de octubre del mismo año. Sabiendo era buscado con gran interés, pidió y logró ser admitido en el Asilo de ancianos por la Superiora de las Hermanitas de los Pobres. Aquí vivió oculto hasta el 6 enero de 1938, cuando todos los sacerdotes fueron puestos en libertad. Desde esta fecha paseó y salió como los demás asilados.

Don José Tarrés y Rosell, de 63 años de edad. Chantre desde el año 1924. En 7 Septiembre de 1936 los milicianos registraron su domicilio apode- 
rándose del dinero, valores, alhajas, cáliz, etc y obligándole a quemar imnágenes y objetos del Oratorio, algunos de manifiesto valor. En 30 octubre del mismo año fue detendio, despojado de todo, y recluido en el Preventorio de donde salió el 14 Noviembre para el Asilo de las Hermanitas de los Pobres. El 6 de Enero de 1938 obtuvo la libertad, sin encontrar nada de cuanto tenía en su domicilio.

Don José Barguñá y Boxa, de 61 años de edad, Maestreescuela desde el año 1931. Los sucesos le encontraron en San Hilario Sacalm, de donde, al notar el peligro que corría, salió para Barcelona. Fue detendio el día 20 de marzo de 1937 y llevado a la cárcel modelo, donde permaneció hasta el 30 de julio del mismo año, habiendo sido juzgado y puesto en libertad. Un desaprensivo ocupó su domicilio y utilizó su mobiliario. En 13 Septiembre de 1938 se trasladó, con pasaporte, a Francia y Bélgica, donde permaneció hasta poco después de ser agregada nuestra provincia a la España nacional.

Don José Morera y Sabater, de 52 años de edad, Doctoral desde el año 1915. Desde el comienzo de la revolución no salió de su domicilio. El dia 7 de Noviembre de 1936 fue despojado de todo por el llamado Comité de Incautaciones, detenido y, salvando la vida de un modo providencial, recluido en el Preventorio. Obligado a trabajos forzados, el 23 de Noviembre se le encargó el arreglo y ordenación del archivo de la Diputación, en cuya labor se ocupó un año con otros compañeros por él escogidos. Una afección de la piel motivó su ingreso en el Hospital el 22 de Junio donde permaneció hasta que fue puesto en libertad el 22 de Julio de 1937. Continuó acompañando a sus compañeros reclusos en el arreglo del Archivo Provincial, procurándoles las posibles ventajas en la comunicación con sus familiares, hasta que se consiguió la libertad de todos. Después prestó eficaz ayuda en la organización y orientación de las actividades religiosas de la ciudad y del Obispado.

Don Calixto Mas Casterad, de 61 años de edad, Canónigo desde el año 1919. La persecución religiosa le cogió fuera de la ciudad, pues hacía varios años que por motivos de salud obtenía dispensa de residencia. Soportó también diversos atropellos. Mitigado el furor persecutorio en 1937 fue a Barcelona, donde pudo facilitar el paso a Francia de varias Religiosas. Fue también detendio y puesto en libertad poco después. 
Don Andrés Compta Masmitjá, de 70 años de edad, Canónigo Penitenciario desde el año 1921. Fue desposeído de los que tenía en el Seminario de Gerona y en la Casa Misión de Bañolas, evitó la persecución viviendo oculto hasta el 14 de Julio de 1937. En esta fecha, hallado en un registro policíaco ingresó en el Preventorio judicial, siendo puesto en libertad provisional el 11 de Octubre del mismo año. Poco después fue juzgado y absuelto pasando a residir con su familia, cerca de Bañolas, donde trabajó con celo en el restablecimiento privado del culto religioso y frecuencia de sacramentos.

Don Esteban Canadell Quintana de 59 años de edad, Canónigo desde el año 1921. Siendo Vicario General sufrió varios registros desde los primeros días. Fue desposeído de su domicilio, que ocuparon con sus muebles, por orden de un Comité, las Religiosas Josefinas. Ingresó en el Preventorio el día 24 de Septiembre de 1936, siendo trasladado poco después al Asilo de las Hermanitas de los Pobres, desde donde en Marzo de 1937 salió ocultamente para Francia, pasando desde allí a la España Nacional. Regresó después de liberada la ciudad.

Don Francisco Franch y Vila, de 56 años de edad, Canónigo desde el año 1923. Fue interrogado varias veces por Comités estando casi ciego en su domicilio. Para consultar un especialista pudo trasladarse a Barcelona donde estuvo oculto por algún tiempo. Habiendo regresado de nuevo, vivió fuera de su domicilio varios meses volviendo más tarde al mismo, sin que afortunadamente hubiera de soportar atropellos especiales.

Don Rufino Noales Hernández, de 60 años de edad en 1937, Canónigo desde el año 1925. Cuando estalló la revolución hacía pocos días que había llegado a Orihuela, donde solía pasar el verano con su familia. Allí falleció de un ataque cardíaco en 24 de Septiembre de 1937 "víctima de los sufrimientos propios del período que hemos vivido" según comunicación de la Secretaría de Cámara de aquella diócesis. R.I.P.

Don José María Carbó Cuscó, de 54 años de edad, Canónigo desde el año 1926. Estaba predicando en San Miguel de Campmajor cuando estalló la revolución. El 30 de Julio pudo regresar a Gerona pero viendo acrecentarse el peligro huyó a San Hilario Sacalm, disimulando el chófer su calidad de sacerdote al preguntar acerca de ella la patrulla de Sta Coloma. Allí vivió oculto hasta el 4 de Junio de 1937 que se trasladó a Parlabá, re- 
gresando a su domicilio el $1^{\circ}$ de enero de 1938 , habiendo perdido en un registro su biblioteca y mobiliario del despacho.

Don Domingo Campmol Freixanet, de 59 años de edad, Canónigo desde el año 1926. Al principio de la revolución marxista considerando su vida en peligro pasó la frontera estableciéndose en Perpignan, en cuyo seminario ejerció el profesorado. Desplegó notable actividad en proteger y apoyar a los jóvenes, principalmente sacerdotes, seminaristas y de acción católica, que entraban en Francia para dirigirse a la España Nacional. Mitigada la persecución, sirvió de intermediario al Prelado para comunicarse con sus diocesanos las pocas veces que pudo efectuarlo. Poco después de liberada la ciudad se reintegró a esta residencia.

Don José Costa Vivés, de 57 años de edad. Canónigo Lectoral desde 1928. Ejercía el cargo de Secretario de Cámara del Obispado. Fue detenido el día 4 de Agosto en la Comisaría de Vigilancia, ingresando en la cárcel el dia 16 del mismo mes. El 7 de Enero de 1937 pasó al Asilo de las Hermanitas de los Pobres en calidad de preso, y se le puso en libertad el 6 de Enero de 1938. Continuó residiendo en el benéfico establecimiento hasta el bombardeo del 29 Enero del siguiente año, pocos días antes de la liberación. Asumió el gobierno de la diócesis en ausencia del Prelado y de su Vicario y a partir del 1938, cuidó de ir ordenando prudentemente las cosas que la persecución y el celo indiscreto de muchos habían confundido y embrollado.

Don Hermenegildo Planadecursach y Deu, de 61 años de edad, Canónigo pontificio desde el año 1934, pudo residir en su piso hasta el 24 de septiembre de 1936, en cuya fecha se trasladó a Cassá de la Selva, donde permaneció hasta la venida del glorioso ejército libertador.

Don Santiago Estebanell Suriñach de 70 años de edad, Canónigo desde el año 1935. La revolución le cogió en Madrid, donde estaba tramitando asuntos de la diócesis de Málaga. Varias veces sufrió registros y vejaciones, pero no ingresó en la cárcel. Habiéndose trasladado a Valencia el dia 10 de agosto de 1936 fue detenido en la estación de aquella capital, llevado al control de los milicianos, registrado y escoltado por ellos hubo de subir a un coche a las 11 y media de la noche, siendo llevado a la plaza de Toros. Afortunadamente funcionaba una Inspección de milicias voluntarias, la cual, viendo sus documentos en regla, ordenó a los milicianos retirarse, 
acompañándole un teniente del ejército al Hotel, desde donde pudo regresar a Madrid el siguiente día. En Diciembre del mismo año se evacuó a Murcia y en 1937 ingresó en el Asilo de las Hermanitas de los Pobres de Lorca en cuyo benéfico establecimiento ejerció el cargo de portero, hasta el momento de la liberación. En esta Casa las Religiosas vistieron siempre el Santo hábito y gozaron de dulce compañía de Jesús sacramentado.

\section{Rdos beneficiados}

Don Manuel Serrano y Serrano, de 69 años de edad. Beneficiado desde el año 1895 y ya jubilado. En 24 de septiembre de 1936 después de registrado su domicilio fue llevado al Asilo de las Hermanitas de los Pobres, donde permaneció hasta el 1 de febrero de 1939.

Don José María Vallverdú Masdeu, de 69 años de edad, Beneficiado desde el año 1901. Fue desposeído del mobiliario de su piso y llevado al Asilo de las Hermanitas el día 24 de septiembre, donde permaneció hasta la liberación. Reanudada la vida residencial, enfermó el dia 4 de junio, falleciendo el 9 del mismo mes, después de recibir los Santos Sacramentos. R.I.P.

Don Francisco Poves y Poves, de 69 años de edad, Beneficiado desde el año 1907. El día 24 de septiembre de 1936 fue detenido ingresando en el Preventorio. El 13 de Noviembre fue trasladado al Asilo de las Hermanitas, donde permaneció hasta la liberación.

Don Arturo Costa Suriñach, de 68 años de edad, Beneficiado desde el año 1908. Vivió en su domicilio todo el tiempo de la tiranía marxista, sufriendo un registro el 18 de noviembre, durante el cual fue amenazado con pistolas. Allí hubo de permanecer oculto por espacio de trece meses acechado de continuo por un jefe de milicianos. Alcanzada una relativa calma, se aventuró a salir de su encierro, sobreviniéndole entonces nuevo peligro por dar cobijo a desertores. Quedó sumido en la miseria y con la salud quebrantada.

Don José Trías Montaner, de 57 años de edad, Beneficiado Barítono desde el año 1913. Fue llevado al Preventorio judicial el día 24 de septiembre de 1936. Al ser sometidos a trabajos forzados los sacerdotes presos, trabajó de peón albañil, a pico y pala, por espacio de ocho meses. Fue de 
los no comprendidos en el auto de procesamiento que se dictó el 5 de enero de 1937; por lo cual con sus compañeros de condición hubo de comparecer ante la Audiencia el 12 de Agosto de 1937; y no hallando motivo para procesarlos el mismo día fueron puestos en libertad. Cuando se logró cierta tolerancia, organizó cautelosamente el culto en su residencia.

Don Juan Itchart y Pimás de 55 años de edad, Beneficiado Salmista desde el año 1915. En 12 septiembre de 1936 fue detenido en su domicilio y conducido al Comité de Justicia e Incautación siendo libertado al día siguiente. Trasladóse más tarde a Pineda siendo nuevamente detendio allí el día 4 Diciembre y llevado a Barcelona donde pasó 15 días en los calabozos de la Jefatura de Policía, ingresando después en la Cárcel Modelo. Obtuvo la libertad el dia 2 de Noviembre de 1937, volviendo a Gerona en espera de la liberación de esta ciudad y provincia.

Don Mateo Durán y Real, de 40 años de edad, Beneficiado Sochantre desde el año 1925. Habíase acogido a la hospitalidad de unos amigos cuando, al estallar la revolución, los sacerdotes que moraban en el Seminario recibieron orden de evacuarlo. Allí sufrió un registro, en el cual fue desposeído de lo que había llevado consigo e ingresó como detenido en las cuadras de la casa donde se hallaba instalado el llamado Comité de Justicia e Incautaciones, pasando días después al Preventorio. Sometido a trabajos forzados, formó parte de la brigada encargada del arreglo del Archivo provincial. No siendo procesado a pesar de estar preso cerca de un año, obtuvo la libertad el 12 de agosto de 1937. Después formó parte del profesorado de una Academia particular hasta poco antes de concluir la dominación roja.

Don Luís Doménech y Torrent de 42 años de edad, Beneficiado Sochantre desde 1925. Fue detendio en Barcelona por las patrullas de control el 23 de Enero de 1937, y conducido a Horta, y de allí a las pocas horas a la checa de San Elías, donde estuvo hasta el 5 de febrero. Conducido a la Jefatura de Policía pasó un día en sus calabozos, siendo llevado a Montjuich, donde permaneció hasta el 14 de abril, día que ingresó en la Cárcel Modelo. Fue puesto en libertad el 14 noviembre de 1937. Vino a Gerona, desde donde fijó su residencia en la villa de Mieras, siendo nuevamente detenido ingresando en la cárcel de esta ciudad, acusado de escuchar radio Salamanca, en 4 de Marzo de 1938. Juzgado y absuelto en 8 Abril del 
propio año, dejó de ser atropellado hasta el 28 de Enero de 1929 [sic], que fue detenido por una patrulla de recuperación, logrando escapar en las mismas puertas del cuartel, de manos de los soldados.

Don José Morell Aragonés, de 56 años de edad, Beneficiado desde el año 1926. Sufrió en su casa ocho registros. Detenido por los milicianos el ocho de Septiembre, estuvo en la cárcel de esta ciudad hasta el 19 de octubre. Fue a refugiarse en Pineda su pueblo natal en casa de sus hermanos, donde los milicianos le metieron dos veces en la cárcel, aunque por espacio de pocas horas. Allí le detuvo la policía de Barcelona junto con otros seis vecinos del mismo pueblo, llevándole preso a Montjuich el 24 Diciembre de 1936, siendo trasladado al cabo de unos meses a la Cárcel Modelo y puesto en libertad el 16 Noviembre de 1937, después de cuya fecha no fue objeto de molestias especiales.

Don José Prunell y Sureda, de 38 años de edad, Beneficiado Salmista desde el año 1928. Estuvo detenido el 12 de Agosto de 1936 desde las once de la mañana hasta las nueve de la noche. El día 10 de enero de 1939 al ser llamado su reemplazo a filas, se presentó para esconderse luego hasta la llegada a esta ciudad, de las tropas nacionales.

Don Joaquín Aluart y Maset, de 49 años de edad, Beneficiado desde el año 1930. Durante la revolución marxista estuvo detenido por disposición de Creixans, presidente del Comité ejecutivo, en su domicilio particular hasta el 24 septiembre de 1936, en cuya fecha fue conducido por los milicianos al tribunal popular, luego a la Comisaría de Vigilancia y por la noche del mismo día al Preventorio. Procesado y sometido a trabajos forzados, como la mayor parte de sus compañeros sacerdotes, actuó de peón albañil en varias obras y después de pintor en la misma cárcel. Sobreseídas las causas sacerdotales por auto de 18 de Julio de 1937. Puesto en libertad se trasladó a su pueblo de Salitja, pasando desde allí a Mataró en marzo de 1938.

Don José Esteva y Juana, de 73 años de edad, Beneficiado Maestro de Ceremonias desde el año 1903. Sufrió en su casa dos registros en los que los milicianos con gran aparato de fuerza y amenazas saquearon todo llevándose dineros y valores. Respetaron de algun modo su persona, pues no le pusieron preso; solamente le obligaron a presentarse en Comisaría dejándole luego en libertad. 
Don Juan Perramón y Oliva, de 50 años de edad, Beneficiado con cargo de Maestro de Capilla desde el año 1923. Estuvo recluido en su domicilio hasta el 17 de Noviembre de 1936, en cuya fecha con motivo de un registro en otras casas vecinas, fue detendio e ingresó en el Preventorio. A las pocas horas después de habérsele tomado declaración, fue trasladado a la antigua cárcel, en el segundo piso, separado de los otros presos por igual causa. Pasado de nuevo al Preventorio al cabo de trece días, fue agregado a la brigada de trabajadores, o sea sometido a trabajos forzados. Recobró la libertad el 28 Diciembre de 1937; pudo desde entonces residir nuevamente en su casa sin especiales atropellos.

Don Bruno Bojons y Ribas, de 70 años de edad, Sacristán menor de esta Catedral desde 1899 a 1914, y Beneficiado Silenciero de la misma desde el año 1929. Soportó veintidos registros en su piso vecino a la Catedral, cinco de ellos de noche. El dia 25 de Julio de 1936 fue bárbaramente apaleado, y al siguiente le obligaron a atravesar las calles céntricas de la ciudad que van de esta Santa Iglesia a la Comisaría de Vigilancia cargado con ocho candelabros de plata. Al regreso le metieron en un coche del cual le hizo bajar un bienhechor desconocido. El 24 de septiembre fue preso y recobró la libertad al cabo de un mes, poco más o menos, pudiendo regresar a su domicilio.

Don Juan Guix y Marsal, de 38 años de edad cuando fue asesinado en 1936. Había nacido en La Piña y cursado sus estudios en este Seminario. De manos del Sr Obispo de Barcelona, vacante la sede gerundense, recibió el Subdiaconado en las témporas de la Sma Trinidad del año 1922: el Diaconado y Presbiterado en la iglesia de San Esteban de Bañolas en los domingos once y trece después de Pentecostés, días 29 de Agosto y trece de Septiembre del mismo año. Poco después se le nombró coadjutor de Castellfullit de la Roca, cargo que sustituyó el 14 de Julio de 1924, por el de Sacristán de la parroquia del Mercadal de esta ciudad. A los pocos meses dejó este último cargo, siendo nombrado coadjutor de Besalú, y después de Santa Pau en agosto de 1927. Previa oposición, obtuvo el beneficio de Tenor y de la Pasión y Muerte, a él unido, tomando posesión el 4 de Marzo de 1929. Era delgado de complexión, de estatura regular, de carácter tímido, de dulce y afable trato, buen cantor y sacerdote piadoso y ejemplar. Cuando la infausta república echó a los padres jesuitas de su 
residencia y hubieron de abandonar el templo del Sagrado Corazón de Jesús que tenían a su cuidado, fue nombrado sacristán del mismo el Rdo. Guix. Desencadenada la persecución religiosa, el dia 13 de agosto de 1936 se encontraba casualmente en el piso que ocupaban unos padres jesuitas, cambiando impresiones con el recién llegado P. Joaquín $\mathrm{M}^{\mathrm{a}}$ Valentí; cerrada la noche presentáronse allí sujetos armados y obligándolos a subir a un coche los fusilaron en las afueras de la ciudad. Es fama que su verdugo J. Creixans halló la muerte en el mismo sitio en que sacrificó al Rdo Guix y a los tres padres de la Compañía de Jesús. Sus restos fueron trasladados a la ciudad, con los de sobre noventa víctimas el 27 de abril de 1939 y llevados al cementerio al día siguiente, acto que constituyó una imponente manifestación de duelo. R.I.P.

Don Juan Pujol y Serrat, de 40 años de edad, Sacristán menor desde mayo de 1936. Al estallar la revolución permaneció oculto en su casa hasta el 9 septiembre. Asesinado su vecino Rdo Matas, se trasladó a Olot, pasando la frontera en abril de 1937 y por Francia a la zona Nacional. Liberada en parte Cataluña fue encargado de la parroquia de Tragó de Noguera (Lérida), hasta que se reintegró a la Sacristía de esta Iglesia Catedral. 